\title{
Effect of the Wildfires on Sandy Podzol Soils of Nadym Region, Yamalo-Nenets Autonomous District, Russia
}

\author{
Evgeny Abakumov, ${ }^{1}$ Alexandr Pechkin, ${ }^{2}$ Ekaterina Chebykina (Maksimova) (D), \\ and Georgii Shamilishvili ${ }^{1}$ \\ ${ }^{1}$ Department of Applied Ecology, Faculty of Biology, Saint-Petersburg State University, Saint-Petersburg 199178, Russia \\ ${ }^{2}$ Research Center of the Yamal-Nenets Autonomous District, Salekhard 629008, Russia \\ Correspondence should be addressed to Ekaterina Chebykina (Maksimova); doublemax@yandex.ru
}

Received 21 April 2020; Revised 10 August 2020; Accepted 3 September 2020; Published 22 September 2020

Academic Editor: Oliver Dilly

Copyright (C) 2020 Evgeny Abakumov et al. This is an open access article distributed under the Creative Commons Attribution License, which permits unrestricted use, distribution, and reproduction in any medium, provided the original work is properly cited.

\begin{abstract}
Active land disturbance of soil and environments appears even in remote landscapes of tundra and forest tundra. Wildfires become a frequent factor of soil degradation and intensification of permafrost degradation, also affecting the global balance of carbon, especially content and distribution of polycyclic aromatic compounds. Mature unaffected by fire sandy-textured podzols soils were investigated in comparison with the same soil strongly affected by surface fire in the end of August 2016 in surroundings of the Pangody settlement, Nadym district, Yamal region. Data obtained showed an intensive morphological transformation of the topsoil layers, decreasing total organic matter and apparently increasing the humus enrichment by nitrogen. Wildfires also result in complete transformation of the fractional composition of the polycyclic aromatic compounds. The sum of PAHs increases intensively as well as benzo(a)pyrene content in soils. Therefore, soils of the cryolithozone become more faced to the wildfires during the last decades. Even one-time fire effect results in serious transformation of soil geochemical state.
\end{abstract}

\section{Introduction}

Anthropogenic successions caused by climate dynamics and effects of natural (windfalls and pests irruption), natural and anthropogenic (wildfires), and anthropogenic (logging) phenomena are characteristic of tundra and forest ecosystems. The human impact on natural biogeocenoses, which becomes more actual nowadays, leads to a change in ecosystems functioning and makes monitoring work extremely important. An important factor, disturbing natural processes in ecosystems, is wildfires, whose consequences are difficult to predict. Wildfires are given special attention in natural ecosystem surveys. A considerable body of work existing in the science literature is about the forest fires role in the forest cover natural dynamics as they are the most important environmental factor among others that determine the structure and dynamics of forests and, accordingly, the ecological territory state [1-5]. A lot of attention is paid to the problem of postpyrogenic soil change, its properties, soil regime, and functions in a boreal zone. A variety of research studies are devoted to pyrogenic transformation of the water regime, vegetation, and forest landscapes in whole [6-15]. However, data on similar studies of the pyrogenic transformation in polar, tundra, and subboreal landscapes of cryolithozone are extremely rare in the literature. The main directions in this field are research studies on postpyrogenic transformation of plant cover. Therefore, the purpose of this work is to study soil changes after wildfires affect the cryolithozone of tundra and foresttundra ecosystems.

Besides, scientific interest in PAHs has continued unabated over the last decades since the temperature effects on soil organic matter (SOM) are considered the most common way of the PAH formation.

PAHs' anthropogenic sources of pyrogenic origin (vehicles, industrial facilities, energy facilities, and others emissions) have been studied in detail so far. At the same 


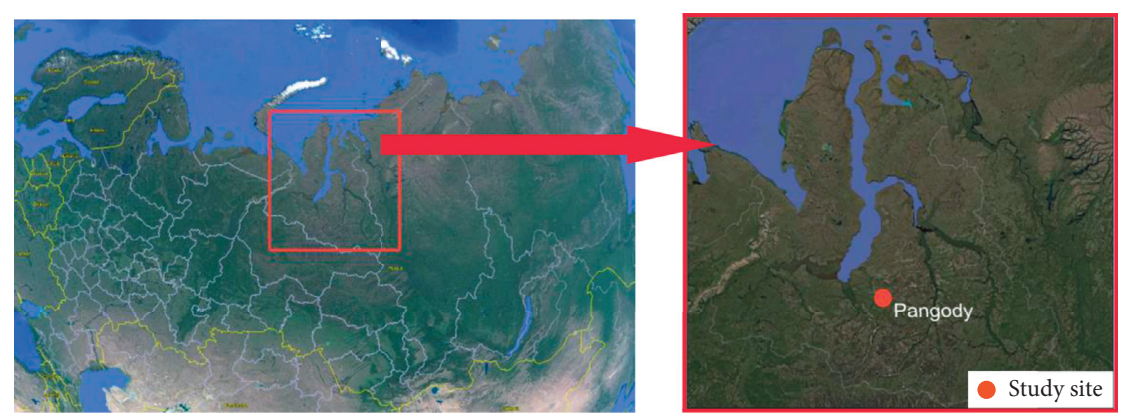

Figure 1: The study site location. The source of this map is Google Earth Pro (https://www.google.com/intl/ru/earth/).

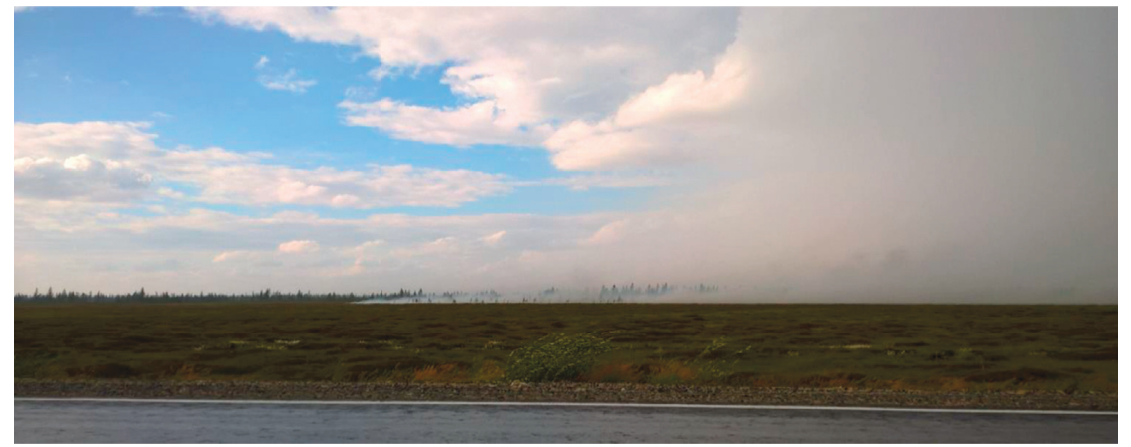

FiguRe 2: Surface fire in forest-tundra landscape, surroundings of the Pangody settlement.

time, there is a trend to reduce the PAH pollution of various landscape components in developed countries due to improved technologies and environmental standards [16, 17].

Therefore, increasingly greater attention is paid to natural pyrogenic sources of PAHs such as volcanism and wildfires. Volcanic sources of PAHs are very local, but forest, steppe and peat fires damage significant areas annually, which is considered as one of the global factors of $\mathrm{PAH}$ environmental release. Besides, the world literature contains numerous laboratory experiment data on the possibility of $\mathrm{PAH}$ formation from vegetation components; moreover, burning conditions (temperature and oxygen access) and a vegetation type significantly influence on the quantity and structure of the compounds formed.

A more detailed review on this issue was given by Tsibart and Gennadiev [18]. At the same time, the trend of the pyrogenic $\mathrm{PAH}$ accumulation in landscapes, especially in soils as a deposit environment, has not been practically studied. Individual publications are devoted to investigation of PAHs in fire-affected soils of different genesis [19-25]. But still there are no enough data in the literature on the composition, quantity, and distribution of PAHs in soils coming from wildfires, particularly in the north region of cryolithozone. North polar ecosystems are characterized by low resistance to anthropogenic impact against the background of high resource potential. There are some works that aimed at peculiarities of PAH accumulation in tundra ecosystems under the different influences, for example, Yakovleva et al. [26], but fire effect was not investigated yet.
The main objective of this work is to investigate PAHs in the initial stage of the demutation postfire sequence of postpyrogenic soils.

\section{Materials and Methods}

2.1. Study Site and Soil Sampling. The research object is located near Pangody settlement, Nadym district, Yamal region, Western Siberia, Russia (see Figures 1 and 2) (N 6550-356, E 074-24-210). The study plots are represented by forest-tundra ecosystem, sublayered by stratified parent material, namely, sand sublayered by silty textured permafrost grounds (on the depth of $1.7 \mathrm{~m}$, morphologically measured). The objects of investigation for comparison fire effect are two soils pits ( 2 soil profiles) presented by mature soil, podzol (according to WRB podzols), and fire-affected soil, which was initially the same with mature podzol soils. The control plot contained plant cover and soil unaffected by wildfire and was situated close to the fire-affected plot. The surface fire event occurred in 2016, at the end of the summer. Soil samples were taken in 2016 too, immediately after the fire. Soil samples were selected from each horizon in three replications with an aim to analyze basic chemical properties: (1) podzol, mature soil, unaffected by wildfire; stratification of layers is folic-albic-spodic-podzol (according to WRB) and O-E-BF-BC-C (according to Russian soil classification); (2) podzol, affected by fire, stratification of layers is folic pyr-albic $_{\text {pyr }}$-spodic-podzol (according to WRB) and Opyr-Epyr-BF-BC-C (according to Russian soil classification). So, the fire effect on soil macromorphology is 


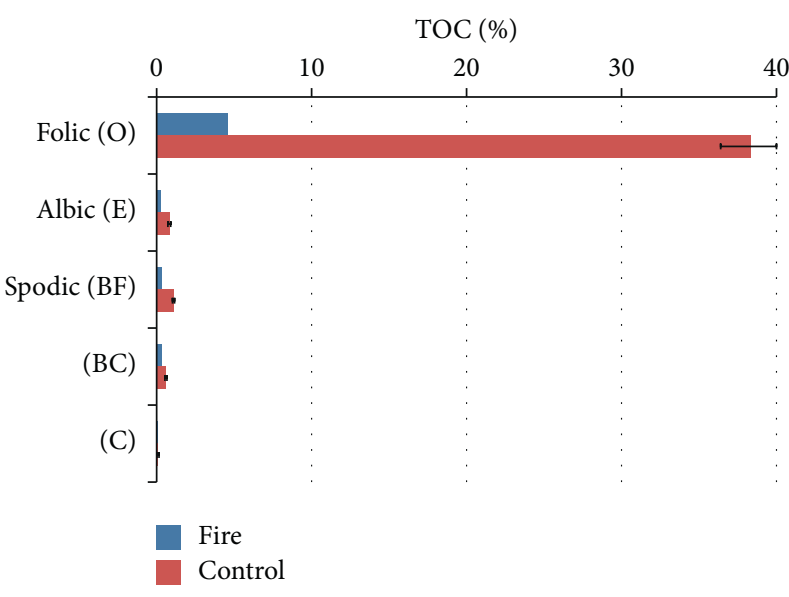

(a)

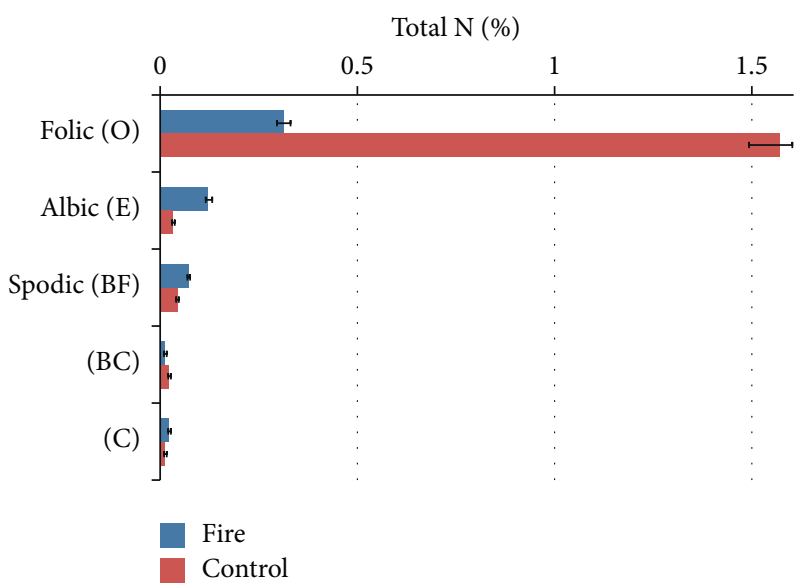

(b)

FIgURE 3: The profile distribution of total organic carbon (a) and nitrogen (b).

pronounced only in the topsoil or superficial soil horizons. Two soil pits were investigated (at unburned site as a control and at surface fire plot); totally, more than 30 individual soil samples were sampled for further chemical analyses in laboratory and were analyzed.

\subsection{Chemical Analyses of the Fine Earth. Air-dried soil} samples were grounded and passed through a $2 \mathrm{~mm}$ sieve for further analysis of fine earth. Analyses were conducted in the certified laboratory of St. Petersburg State University at the Department of Applied Ecology, Russia. Soils were analyzed according to the following methods: determination of actual acidity $(\mathrm{pHw})$ and potential soil acidity $\left(\mathrm{CaCl}_{2}\right)$. Soil microbial respiration was determined using incubation chambers. An element analyzer Euro EA3028-HT Analyzer was used for determination of $\mathrm{C}$ and $\mathrm{N}$ content in SOM, a $\mathrm{pH}$ meter $\mathrm{pH}-150 \mathrm{M}$ for assessing $\mathrm{pH}$ in water and in salt suspensions.

Concentrations of following 14 polynuclear aromatic hydrocarbons (PAHs) and its total sum were studied:

Acenaphthene (ANA)

Anthracene (ANT)

Benzo(a)anthracene (BaA)

Benzo(a)pyrene (BaP)

Benzo(b)fluoranthene (BbF)

Benzo(g,h,i)perylene (BPE)

Benzo(k)fluoranthene (BkF)

Chrysene (CHR)

Dibenz(ah)anthracene (DBA)

Fluoranthene (FLT)

Fluorene (FLU)

Naphthalene (NAP)

Phenanthrene (PHE)
Pyrene (PYR).

National standard method PND F $16.1: 2: 2.2: 3.62-09$ [27], US EPA method 8310 [28, 29], and publications of D.N. Gabov [30, 31] were used for PAH content analysis. The US EPA method 3550b [29] was used for PAH extraction. It consists of ultrasonic treatment via Branson 5510 ultrasonic bath (USA, power $469 \mathrm{~W}$, working frequency $42 \mathrm{kHz}$ ) at room temperature with methylene chloride (high purity grade).

Kuderna Danish concentrator (Supelco) was used for solvent removal (evaporation). The US EPA purification method 3660c (1996) for refining PAHs fractions is focused on consecutive chromatography in columns filled with aluminum oxide (Brockman activity grade 2-3, Neva Reaktiv) and silica gel (Fluka). The absence of peaks in the blank chromatogram meant the purity of PAH fractions. Standard PAH solutions were prepared using a standard mixture of 14 PAHs (Supelco) (concentrations of each component in the range of $\left.100-2000 \mu \mathrm{g} / \mathrm{cm}^{3}\right)$. A reversephase HPLC (high-performance liquid chromatography) was used for analysis of components and quantities of PAHs in soils. This analysis was made in gradient mode with spectrofluorimetric detection via chromatograph "Lyumahrom" ("Lumex", Russia) at $30^{\circ} \mathrm{C}$ on a column Supelcosil $^{\mathrm{TM}}$ LC-PAH n $5 \mu \mathrm{m}(25 \mathrm{~cm} \times 2.1 \mathrm{~mm})$. Mobile phase was provided with acetonitrile-water gradient. A special valve was used for injection of $10 \mu \mathrm{l}$ volume samples. Individual PAHs were identified by the time of retention. And then components' fluorescence spectra from the column were compared with standard $\mathrm{PAH}$ spectra. PAH quantity was determined using the external standard method. Moreover, the same procedure was performed for standard reference materials (1944 New York/New Jersey Waterway Sediment (National Institute of Standards and Technologies NIST, USA)) that contain a mixture of 14 PAHs in order to assure the quality. An error of $\mathrm{PAH}$ determination (in particular benzo(a)pyrene) in the soils was 35\% in the range 


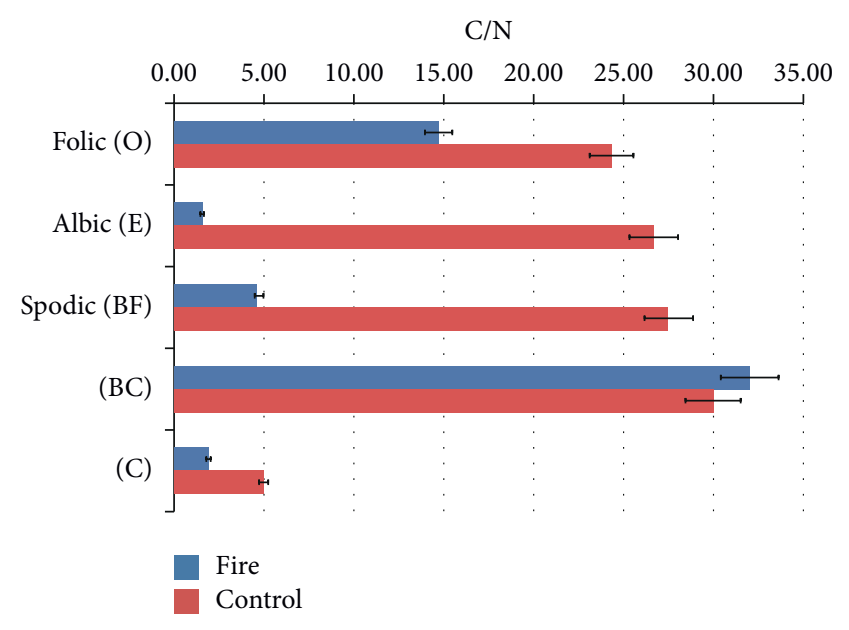

Figure 4: $\mathrm{C} / \mathrm{N}$ ratio in control and fire-affected soils.

of $5-40 \mathrm{ng} / \mathrm{g}$ and $25 \%$ in the range of $40-2000 \mathrm{ng} / \mathrm{g}$ with a confidence probability of $P=0.95$. There are standards for the benzo(a)pyrene content in the soils $(20 \mathrm{ng} / \mathrm{g})$ in Russian legislation (GN 2.1.7.2041-06). The results obtained were compared with these standards. In order to compare the $\mathrm{PAH}$ content with standards for benzo(a)pyrene in soils, benzo(a)pyrene total potency equivalents were calculated by multiplying the concentration of each analyzed individual $\mathrm{PAH}$ in the sample by its benzo(a)pyrene toxic equivalency factor according to the World Health Organization (WHO/ IPCS 1998) scheme. PAH sources apportionment was performed using special molecular markers and ratios, proposed by Yunker et al. [32], and a total combustion PAH index, reported by Hwang and Cutright [33]. Applied markers, such as ANT/(ANT + PHE), FLT/(FLT + PYR), $\mathrm{BaA} /(\mathrm{BaA}+\mathrm{CHR}), \quad \mathrm{IPY} /(\mathrm{IPY}+\mathrm{BPE}), \quad \mathrm{CombPAH} / 14 \mathrm{PAH}$, and $\mathrm{BaP} / \mathrm{BPE}$, are applied in order to distinguish between pyrogenic and petrogenic sources of PAHs. The sum of combustion PAHs (combPAH/14PAH) was used as the tracer of pyrogenic sources. The combPAH/14PAH marker indicates the portion of the sum of combustion-specific compounds in total $\mathrm{PAH}$ content, which are fluoranthene, pyrene, chrysene, benzo(a)anthracene, benzo(k)fluoranthene, benzo(b)fluoranthene, benzo(a)pyrene, benzo(g,h,i)perylene, and indeno(1,2,3-cd)pyrene [34].

All the measurements were performed in triplicate; average values were given with standard error. In order to determine the differences between studied objects, experimental data were statistically treated using Sigma-Plot 8.0 software (calculation of average values, standard deviation, one-way ANOVA, and post hoc test).

\section{Results and Discussion}

In the mature soil, the uppermost horizon was presented by natural forest floor with the thickness of about 5-7 cm, while the thickness of the postfire remnants of the fire-affected soil was only $1-2 \mathrm{~cm}$ and spatially was expended sporadically, namely, in discontinuous form. A new shallow pyrogenic

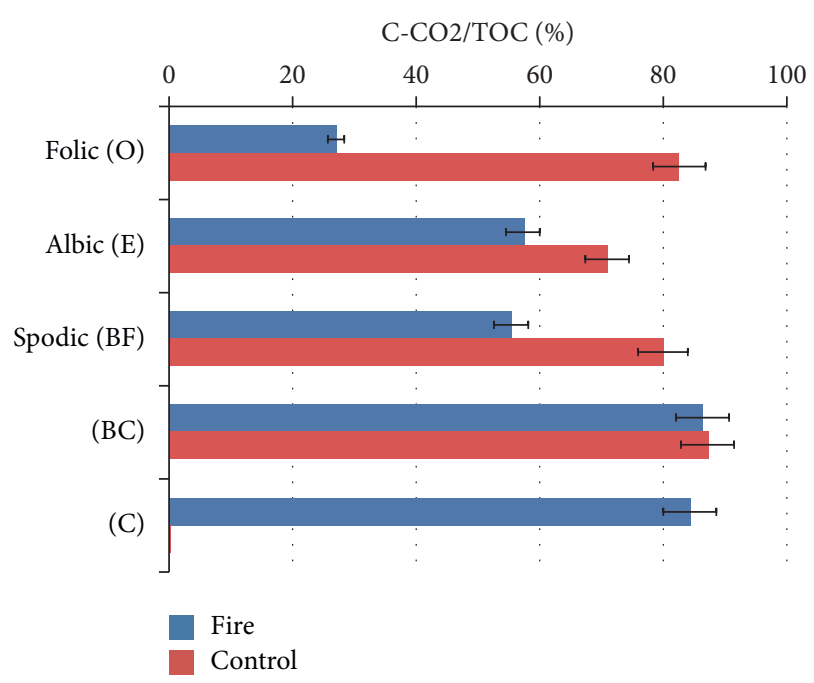

Figure 5: PCM content in control and fire-affected soils.

horizon, whose properties are determined by the presence of abundant coals, is formed [35]. Folic $c_{\text {pyr }}$ and Albic pyr (Opyr and Epyr, respectively) horizons are black layers due the deposition of an ash and charcoal at the soil surface. Organic matter and plant residues are lost from the surface horizons of the soil. It is related to the destruction of the organic horizons, the mineralisation of root residues, and the almost complete absence of fresh plant waste, which could be a material for humification. Moreover, micromorphological characteristics are changed in case of forest fires [36]. A decrease in the porous media was recognised as the main soil development process after the fires as a result of soil porous infilling by ash and charred organic material of different natures. Fire-affected soil has a higher $\mathrm{pH}$ of 5.2 in comparison with increased acidity of $4.7 \mathrm{pH}$ units in a mature soil unaffected by fire.

The total organic carbon content was quite different in soils affected by fire, compared with benchmark ones (see Figure 3(a)). This fact could be interpreted as a result of brief combustion and following losses of soil organic matter under the spontaneous high-temperature fire effect.

The content of nitrogen (see Figure 3(b)) was decreased in soil of postfire plot, but not in proportional ratio with the TOC content. This resulted in the values of $\mathrm{C} / \mathrm{N}$ ratios (see Figure 4) used for estimation of the humus enrichment degree by nitrogen. This index showed that the soil organic matter of fire-affected soil is more enriched by nitrogen organic substances of the mature soil. This was not the result of real changes in organic matter quality due to humification or stabilization. It could be result of apparent enrichment of the humic substance systems by additional accumulation of mineral form of the nitrogen compounds under effect of fireinduced mineralisation and transformation of the SOM. Data obtained are in well correspondence with other pyrogenic soils of Siberia $[7,8,11,15,37]$. A clear maximum of $\mathrm{PAH}$ concentrations in the surface horizons (due to enrichment with organic matter, which is explained by the high absorbing capacity of organic matter in comparison with 


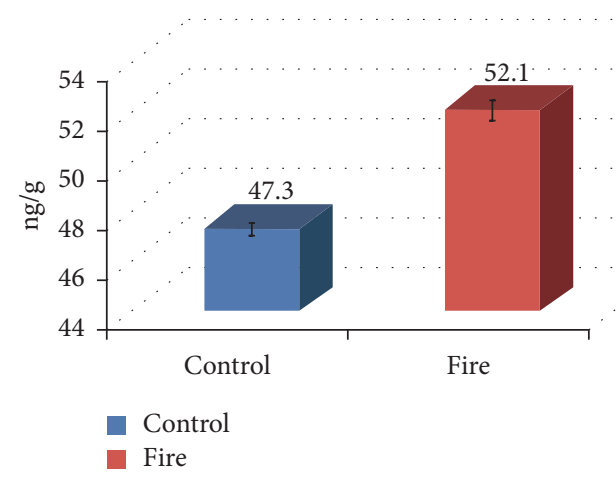

FIGURE 6: Sum of PAH content in folic horizons of control and fireaffected soils: Folic and Folic $c_{\text {pyr }}$, respectively ( $\mathrm{O}$ and Opyr, respectively).

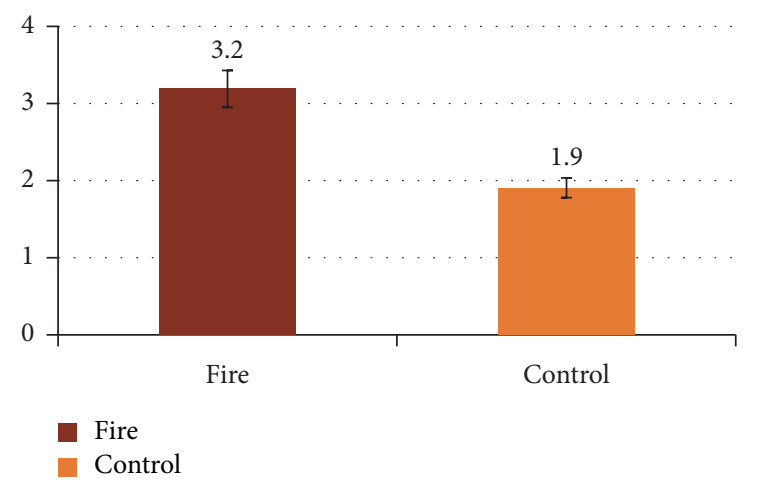

Figure 7: Benzo(a)pyrene content in control and fire-affected soils (folic horizons), ng/g.

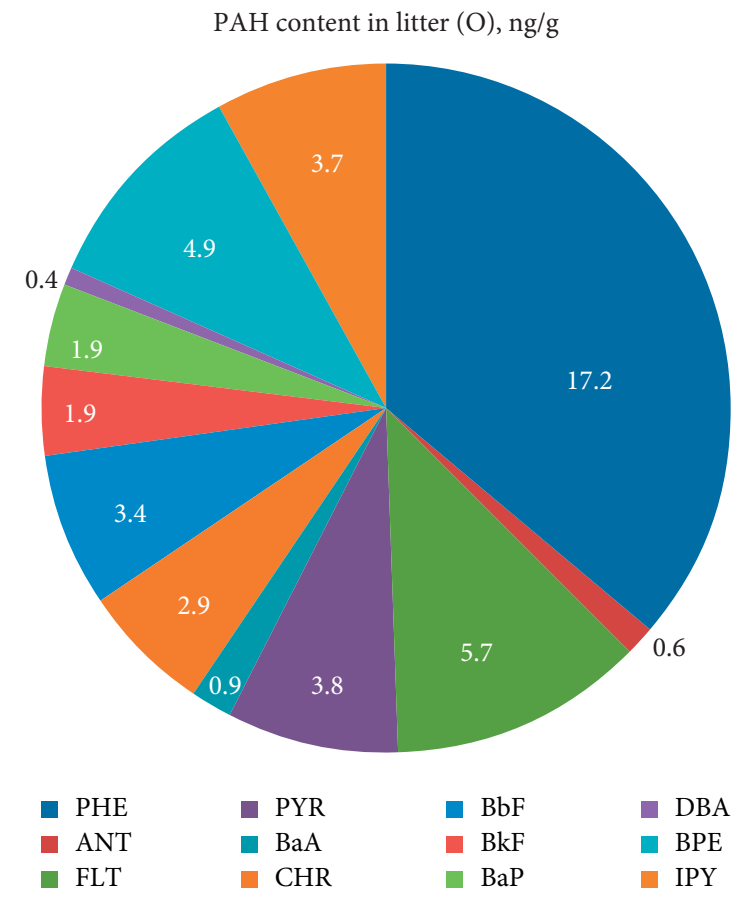

Figure 8: PAH component composition in control soil.

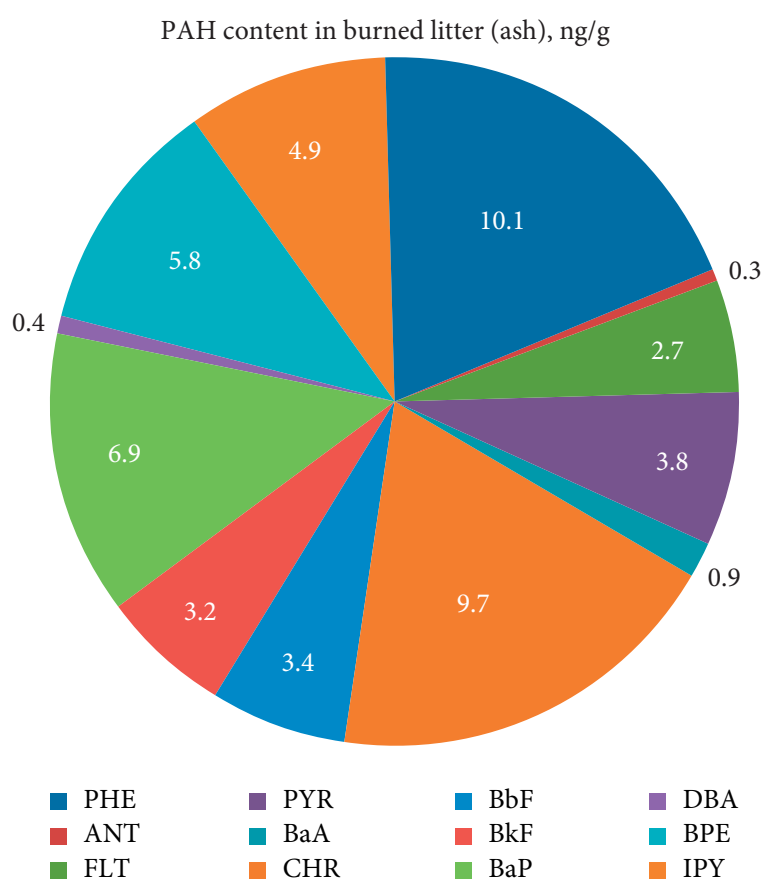

Figure 9: PAH component composition in fire-affected soil.

mineral matter and the main amount of polyarenes from the atmosphere) was not revealed in studied soils as, for example, in podzols near Baikal lake [38].

The PCM (potential mineralizable carbon) values of the mature soil were essentially higher in superficial layers of mature soil than in lower ones. This was also an indicator of the fact that the deepness of fire effect in case of one-time surface fire is not high, and this effect is not pronounced in the deepest soil layers (see Figure 5) Data obtained are comparable with those obtained previously $[16,17,39,40]$.

The total content of PAHs (see Figure 6) in fire-affected soil was higher than in control, and this is caused by pyrogenic factor. The total concentration of the PAH in control soil was comparable with those founded for mature soils of Bely islands [41] and for soils of benchmark merged areas of the Russian Arctic [42]. However, data obtained for podzol are less significant than corresponded data shown by other authors $[43,44]$ and much more than for soils in forest steppe [45]. Pyrogenic processes lead not only to formation of increased total content of the PAHs but also accumulation of benzo(a)pyrene in soils (see Figure 7) and formation of completely different component compositions of the PAHs (see Figures 8 and 9), where the pyrogenic components became dominant.

The calculation of the indexes of the PAHs origin showed that soils under the fires showed accumulation of the petrogenic compounds (FLT/(FLT + PYR $)=0.42$, IPY/ $(\mathrm{IPY}+\mathrm{BPE})=0.46, \mathrm{CombPAH} / \sum \mathrm{PAH}=0.79, \quad$ and $\mathrm{BaP} /$ $\mathrm{BPE}=\mathrm{BaP} / \mathrm{BP}=1.19)$. These indexes were essentially lower in natural soils, which indicate the petrogenic sources of the main PAHs in this soil. This well corresponds with data on $\mathrm{PAH}$ content in soils of the Belyi island with different functional loads, collected previously [40]. However, Dymov et al. [43] showed that content of PAHs such as CHR, FLU, 
TABLE 1: Statistical data analysis.

\begin{tabular}{|c|c|c|c|c|c|c|c|c|c|c|c|c|c|}
\hline $\mathrm{PAH}$ & PHE & ANT & FLT & PYR & $\mathrm{BaA}$ & $\mathrm{CHR}$ & $\mathrm{BbF}$ & $\mathrm{BkF}$ & $\mathrm{BaP}$ & $\mathrm{DBA}$ & $\mathrm{BPE}$ & IPY & $\sum$ PAHs \\
\hline $\begin{array}{l}P \text { value, } \\
\text { ANOVA }(a \\
>0,95)\end{array}$ & 0.05 & $<<0.05$ & $<<0.05$ & 0.22 & 0.73 & $<<0.05$ & 0.5 & $<<0.05$ & $<<0$ & 0.52 & $<<0.05$ & $<<0.05$ & $<<0.05$ \\
\hline $\begin{array}{l}\text { Significance } \\
\text { of differences }\end{array}$ & & 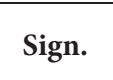 & on & $\tau$ & & Sign. & 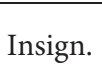 & Sig1 & Si & isig & Sig & Sig & Sig \\
\hline
\end{tabular}

NAP, PYR, and ANT significantly increased in OPIR (L) horizon after wildfires. Only some evidence of the transport pollution has been fixed in natural soils $(\mathrm{BaA} /$ $(\mathrm{BaA}+\mathrm{CHR})=0.24$ and IPY $/(\mathrm{IPY}+\mathrm{BPE})=0.43)$. So, the fire affects not only total concentration of the PAH but also their component composition.

One-way ANOVA analysis revealed significant differences in the content of most individual PAHs (phenanthrene, anthracene, fluoranthene, chrysene, benzo(k) fluoranthene, benzo(a)pyrene, benzoperylene, and idenopyrene), as well as the total PAH content between the control soil and postfire soil $(P \ll 0.05)$ (Table 1$)$.

\section{Conclusions}

Soils of the cryolithozone have faced more wildfires during the last decades. Wildfires become more and more frequent, especially in tundra and forest-tundra in the Western Siberia [46, 47] (http://wiki-fire.org). The podzols soils have been investigated in two plots: not affected by fire and under the influence of the surface fire in August 2016 in surroundings of the Pangody settlement, Nadym district, Yamal region. Data obtained showed an intensive morphological transformation of the topsoil layers decreasing total organic matter and apparently increasing the humus enrichment by nitrogen. Wildfires also result in complete transformation of the fractional composition of the polycyclic aromatic compounds. The sum of PAHs increases intensively as well as benzo(a)pyrene content in soils. The structural composition of the PAHs showed changes under the fire effect: the components of the pyrogenic origin were prevailing in fireaffected soils. Thus, even one-time fire effect results in serious transformation of soil geochemical state.

\section{Data Availability}

The data used to support the findings of this study are available from the corresponding author upon request.

\section{Conflicts of Interest}

The authors declare that there are no conflicts of interest regarding the publication of this paper.

\section{Acknowledgments}

This study was supported by the Grant of Saint Petersburg State University (Urbanized ecosystems of the Russian Arctic: dynamics, state and sustainable development) and
Russian Foundation for Basic Research (project nos. 19-0550107 and 19-416-890002).

\section{References}

[1] M. V. Bannikov, A. I. Pozdnjakov, E. M. Shevchenko et al., "Properties change of pyrogenic and peat soils under the influence of soil formation factors," Moscow State University Bulletin, Series 17, Soil Science, vol. 1, pp. 37-43, 2004.

[2] G. F. S. Boisramé, S. E. Thompson, M. Kelly, J. Cavalli, K. M. Wilkin, and S. L. Stephens, "Vegetation change during 40 years of repeated managed wildfires in the Sierra Nevada, California," Forest Ecology and Management, vol. 402, pp. 241-252, 2017.

[3] V. N. Ilyina, "Pyrogenic impact on plant cover," Samara Bend: Problems of Regional and Global Ecology, vol. 20, pp. 4-30, 2011.

[4] I. S. Melekhov, Forest Science, «Forestry industry», Moscow, Russia, 1980.

[5] K. C. Ryan, "Vegetation and wildland fire: implications of global climate change," Environment International, vol. 17, no. 2-3, pp. 169-178, 1991

[6] M. B. Bodí, D. A. Martin, V. N. Balfour et al., "Wildland fire ash: production, composition and eco-hydro-geomorphic effects," Earth-Science Reviews, vol. 130, pp. 103-127, 2014.

[7] V. V. Bogdanov, A. S. Prokushkin, and S. G. Prokushkin, "Surface fires impact on soil organic matter mobility in larch forests of the cryolithic zone in Middle Siberia," The Bulletin of KrasGAU, vol. 2, pp. 88-93, 2009.

[8] G. Certini, "Effects of fire on properties of forest soils: a review," Oecologia, vol. 143, no. 1, pp. 1-10, 2005.

[9] G. Certini, "Fire as a soil-forming factor," Ambio, vol. 43, no. 2, pp. 191-195, 2013.

[10] E. R. Graber and E. Hadas, "Potential energy generation and carbon savings from waste biomass pyrolysis in Israel," Annuals of Environmental Science, vol. 3, pp. 207-216, 2009.

[11] A. Novara, L. Gristina, J. Rühl et al., "Grassland fire effect on soil organic carbon reservoirs in a semiarid environment," Solid Earth, vol. 4, no. 2, pp. 381-385, 2013.

[12] P. Pereira, A. Cerdà, X. Úbeda et al., "Spatial models for monitoring the spatio-temporal evolution of ashes after fire - a case study of a burnt grassland in Lithuania," Solid Earth, vol. 4, no. 1, pp. 153-165, 2013.

[13] P. Pereira, X. Úbeda, J. Mataix-Solera, M. Oliva, and A. Novara, "Short-term changes in soil Munsell colour value, organic matter content and soil water repellency after a spring grassland fire in Lithuania," Solid Earth, vol. 5, no. 1, pp. 209-225, 2014.

[14] F. R. Zaydelman and J. I. Rydkin, "High plains soils in a forest zone-genesis, hydrology, melioration and use," Eurasian Soil Science, vol. 3, pp. 261-274, 2003.

[15] F. R. Zaydelman and A. P. Shvarov, Pyrogenic and Hydrothermal Degradation of Peat Soils, their Agroecology, Sandy 
Farming Standards, Moscow State University, Moscow, Russia, 2002.

[16] A. N. Gennadiev, J. I. Pikovskij, and V. N. Florovskaja, Geochemistry of Polycyclic Aromatic Hydrocarbons in Rocks and Soils, Moscow State University, Moscow, Russia, 1996.

[17] W. Guo, Y. Pei, Z. Yang, and H. Chen, "Historical changes in polycyclic aromatic hydrocarbons (PAHs) input in Lake Baiyangdian related to regional socio-economic development," Journal of Hazardous Materials, vol. 187, no. 1-3, pp. 441-449, 2011.

[18] A. S. Tsibart and A. N. Gennadiev, "Associations of polycyclic aromatic hydrocarbons in soils affected by wildfires," Moscow State University Bulletin, Series 5, Geography, vol. 3, pp. 13-20, 2011.

[19] H. Chen, A. T. Chow, X.-W. Li et al., "Wildfire burn intensity affects the quantity and speciation of polycyclic aromatic hydrocarbons in soils," ACS Earth and Space Chemistry, vol. 2, no. 12, pp. 1262-1270, 2018.

[20] S.-D. Choi, "Time trends in the levels and patterns of polycyclic aromatic hydrocarbons (PAHs) in pine bark, litter, and soil after a forest fire," Science of The Total Environment, vol. 470-471, pp. 1441-1449, 2014.

[21] M. S. Garcia-Falcoan, B. Soto-Gonzaalez, and J. SimalGaandara, "Evolution of the concentrations of polycyclic aromatic hydrocarbons in burnt woodland soils," Environmental Science and Technology, vol. 40, pp. 759-763, 2006.

[22] F. J. Gonzalez-Vila, J. L. Lopez, F. Martin, and J. C. del Rio, "Determination in soils of PAH produced by combustion of biomass under different conditions," Fresenius' Journal of Analytical Chemistry, vol. 339, no. 10, pp. 750-753, 1991.

[23] S. V. Kakareka, T. I. Kuharchik, L. A. Zanevskaja et al., "Modeling and assessment of PAH emissions on peat bogs after wildfires," Prirodopol'zovaniye (nature management)," The Institute for Nature Management of the National Academy of Sciences of Belarus, Minsk, Belarus, vol. 10, pp. 58-62, 2004.

[24] E. J. Kim, S.-D. Choi, and Y.-S. Chang, "Levels and patterns of polycyclic aromatic hydrocarbons (PAHs) in soils after forest fires in South Korea," Environmental Science and Pollution Research, vol. 18, no. 9, pp. 1508-1517, 2011.

[25] H. Shen, Y. Huang, R. Wang et al., "Global atmospheric emissions of polycyclic aromatic hydrocarbons from 1960 to 2008 and future predictions," Environmental Science \& Technology, vol. 47, no. 12, pp. 6415-6424, 2013.

[26] E. V. Yakovleva, D. N. Gabov, V. A. Beznosikov, B. M. Kondratenok, and Y. A. Dubrovskiy, "Accumulation of PAHs in tundra plants and soils under the influence of coal mining," Polycyclic Aromatic Compounds, vol. 37, no. 2-3, pp. 203-218, 2017.

[27] Pnd F. (Normative Document) 16.1:2.2:2.3:3.6209: Quantitative chemical analysis of soils. A method for measuring of the mass fractions of polycyclic aromatic hydro carbons in soils, bottom sediments, sediments of waste waters, and industrial wastes by high performance liquid chromatography, 2009. (in Russian). Center for Environmental Control and Analysis of the Ministry of Natural Resources of the Russian Federation FSE "CECA" 2013, http://www.gostrf.com/ normadata/1/4293788/4293788763.pdf.

[28] US EPA, "Method 8310: polynuclear aromatic hydrocarbons," in Test Methods for Evaluating Solid Waste, Physical/Chemical Methods, 3rd edition, National Service Center for Environmental Publications (NSCEP) of the US Environmental Protection Agency, Washington DC, USA, 1996a, http:// nepis.epa.gov/Exe/ZyPURL.cgi?Dockey=50000U6E.txt.
[29] US EPA, "Method 3550b: ultrasonic extraction," in Test Methods for Evaluating Solid Waste, Physical/Chemical Methods, 3rd edition, National Service Center for Environmental Publications (NSCEP) of the US Environmental Protection Agency, Washington DC, USA, 1996b, http:// nepis.epa.gov/Exe/ZyPURL.cgi?Dockey=50000U6E.txt.

[30] D. N. Gabov, V. A. Beznosikov, and B. M. Kondratenok, "Polycyclic aromatic hydrocarbons in background podzolic and gleyic peat-podzolic soils," Eurasian Soil Science, vol. 40, no. 3, pp. 256-264, 2007.

[31] D. N. Gabov, V. A. Beznosikov, B. M. Kondratenok, and E. V. Yakovleva, "Formation of polycyclic aromatic hydrocarbons in northern and middle taiga soils," Eurasian Soil Science, vol. 41, no. 11, pp. 1180-1188, 2008.

[32] M. B. Yunker, R. W. Macdonald, R. Vingarzan, R. H. Mitchell, D. Goyette, and S. Sylvestre, "PAHs in the fraser river basin: a critical appraisal of PAH ratios as indicators of PAH source and composition," Organic Geochemistry, vol. 33, no. 4, pp. 489-515, 2002.

[33] S. Hwang and T. J. Cutright, "Biodegradability of aged pyrene and phenanthrene in a natural soil," Chemosphere, vol. 47, no. 9, pp. 891-899, 2002.

[34] F. G. Prahl and R. Carpenter, "Polycyclic aromatic hydrocarbon (PAH)-phase associations in Washington coastal sediment," Geochimica et Cosmochimica Acta, vol. 47, no. 6, pp. 1013-1023, 1983.

[35] A. B. Gyninova, Z. D. Dyrzhinov, A. I. Kulikov, B. D. Gyninova, and B. N. Gonchikov, "Post-pyrogenic evolution of sandy soils under pine forests in the Baikal region,” Eurasian Soil Science, vol. 52, no. 4, pp. 414-425, 2019.

[36] E. Maksimova and E. Abakumov, "Micromorphological characteristics of sandy forest soils recently impacted by wildfires in Russia," Solid Earth, vol. 8, no. 2, pp. 553-560, 2017.

[37] M. A. Nadporozhskaya, B. A. Pavlov, D. M. Mirin et al., "The influence of forest fires on the formation of the profile of podzols," Biosfera, vol. 12, no. 1-2, pp. 32-44, 2020.

[38] T. S. Koshovsky, V. M. Piskareva, T. E. Yazrikova et al., "The effects of forest fire on the content and distribution of PAH in soils of South Baikal region," in Proceedings of the Conference Proceedings "Soil Resources of Siberia: Challenges of the XXI Century, pp. 58-62, Siberia, Russia, December 2017.

[39] E. Abakumov, E. Maksimova, A. Tsibart, and G. Shamilishvilly, "Laboratory assessment of forest soil respiration affected by wildfires under various environments of Russia," International Journal of Ecology, vol. 2017, Article ID 3985631, 2017.

[40] E. Abakumov, G. Shamilishviliy, and A. Yurtaev, "Soil polychemical contamination on Beliy Island as key background and reference plot for Yamal region," Polish Polar Research, vol. 38, no. 3, pp. 313-332, 2017.

[41] G. Shamilishvilly, E. Abakumov, and D. Gabov, "Polycyclic aromatic hydrocarbon in urban soils of an Eastern European megalopolis: distribution, source identification and cancer risk evaluation," Solid Earth, vol. 9, no. 3, pp. 669-682, 2018.

[42] E. V. Abakumov, V. M. Tomashunas, E. D. Lodygin et al., "Polycyclic aromatic hydrocarbons in insular and coastal soils of the Russian Arctic," Eurasian Soil Science, vol. 48, no. 12, pp. 1300-1305, 2015.

[43] A. A. Dymov, Y. .A. Dubrovskii, and D. N. Gabov, "Pyrogenic changes in iron-illuvial podzols in the middle taiga of the Komi Republic," Pochvovedeniye, vol. 2, pp. 144-154, 2014, (In Russ.). 
[44] A. Vergnoux, R. Di Rocco, M. Domeizel, M. Guiliano, P. Doumenq, and F. Théraulaz, "Effects of forest fires on water extractable organic matter and humic substances from Mediterranean soils: UV-vis and fluorescence spectroscopy approaches," Geoderma, vol. 160, no. 3-4, pp. 434-443, 2011.

[45] E. Maksimova, A. S. Tsibart, and E.V. Abakumov, "Polycyclic aromatic hydrocarbons in soils affected with crown and surface fire," Academic Journal "Izvestia of Samara Scientific Center of the Russian Academy of Sciences, vol. 15, no. 3, pp. 63-68, 2013.

[46] A. A. Dymov, E. V. Abakumov, I. N. Bezkorovaynaya et al., "Impact of forest fire on soil properties (review)," Theoretical and Applied Ecology, vol. 4, pp. 13-25, 2018.

[47] S. V. Goryachkin, Soil cover of the North (patterns, genesis, ecology, evolution), GEOS, Moscow, Russia, 2010. 